Dr Radomir S. Gordic, dipl. inž.

\section{VREME REAGOVANJA VOJNIKA VOZACA}

\author{
UDC: $656.13 .052-051: 355.11$
}

Rezime:

Bezbednost vojnog saobracaja i upravljanje kretanjem zavise od vremena reagovanja vojnika vozaca. Vojnici vozaci su selekcionirana grupa vozaca, pa se smatra da je njihovo vreme reagovanja krace od vremena reagovanja generalne populacije vozaca i od nomativnog vremena reagovanja, koje se koristi u analizama. Zbog toga je izvršeno merenje vremena reagovanja vojnika vozaca kocenjem, s ciljem da se sagleda njegov uticaj na bezbednost saobracaja i na upravljanje saobracajnim tokovima, kao i da se strucna javnost upozna sa dobijenim rezultatima. $U$ radu su prikazani rezultati merenja vremena reagovanja vojnika vozaca kocenjem, za slucajno odabranu grupu, u realnim uslovima.

Kljucne reci: vreme reagovanja, bezbednost saobracaja, vojnici vozaci, uporedni uzorak.

\title{
REACTING TIME OF MILITARY SOLDERS
}

\section{Summary:}

Safety in military traffic and its management depends on the reaction time of military drivers. Military drivers are a selected group of soldiers, so it is considered that their reaction time is shonter than the reaction time of general drivers population and it is also shoter than the nomative reaction time, which is used in the analyses. Therefore, the stopping time of military drivers was tested, in onder to see the influence on traffic safety and management of traffic courses, and to interest the professionals in the given results. In the essay results of stopping time in the real conditions for a random chosen group of military drivers are shown.

Key words: reaction time, traffic safety, military drivers, comparative sample.

\section{Uvod}

Vreme reagovanja je najznacajnija subjektivna karakteristika vozaca od koje znatno zavisi bezbednost i efikasnost saobracaja. To je individualna karakteristika, koja zavisi od subjektivnih osobina vozaca i velikog broja objektivnih okolnosti. Kod razlicitih vozaca ovo vreme je razlicito, a kod istog vozaca se menja, zavisno od njegovog psihofizickog stanja i objektivnih okolnosti.

Vojnici vozaci su selekcionirana grupa generalne populacije vozaca. $\mathrm{Na}$ osnovu atributa kojim su selekcionirani, smatra se da je njihovo vreme reagovanja manje od normativnog vremena i od vremena reagovanja generalne populacije vozaca, do kojeg se došlo u prethodnim istraživanjima [1]. Zbog toga je izvršeno merenje vremena reagovanja vojnika vozaca kocenjem ${ }^{1}$ s ciljem da se odrede njegovi statisticki parametri, sagleda njegov uticaj na bezbednost saobracaja i upravljanje kretanjem i da se strucna javnost animira dobijenim rezultatima.

${ }^{1}$ Ovo je tipicni i najcešci oblik reagovanja jer prema [2] na iznenadnu opasnost $80 \%$ vozaca reaguje samo kocenjem, $18 \%$ uz kocenje reaguje i na neki drugi nacin, a $2 \%$ uopšte ne reaguje. 
U ovom radu prikazani su rezultati merenja vremena reagovanja vozaca kocenjem, za slucajno odabranu grupu vojnika vozaca u realnim uslovima.

\section{Vreme reagovanja vozaca $i$ sistema „vozac-vozilo“}

Ukupno vreme koje obuhvata sve procese od momenta kada vozac uoci opasnost (cuje ili vidi) do momenta kada reaguje (prenese nogu na pedalu kocnice i aktivira je ili dejstvuje na upravljac) predstavlja vreme reagovanja vozaca.

U nemogucnosti da se odredi realno vreme reagovanja vozaca, u praksi se koristi prosecno - normativno vreme reagovanja, koje se najcešce ne poklapa sa stvarnim vremenom reakcije. Od realne procene vremena reagovanja vozaca zavisi mogucnost upravljanja vozilom i izbegavanja $\mathrm{SbN}$. U slucaju pogrešne procene vremena reagovanja izvode se pogrešni zakljucci i donose pogrešne odluke, koje se negativno odražavaju na upravljanje i bezbednost saobracaja, pa to može imati ozbiljne posledice.

Vreme reagovanja kocenjem obuhvata vreme reagovanja sistema "vozac-vozilo“ $(\mathrm{v}-\mathrm{v})$, jer se vreme kocenja sastoji od vremena reagovanja vozaca $i$ vremena reagovanja vozila. Reagovanje sistema $\mathrm{v}-\mathrm{v}$ je kompleksan proces složenih psihomotornih aktivnosti za koje je potrebno odredeno vreme, pa se reagovanje vozaca na bilo koju opasnost ne može izvesti momentalno.

Vreme reagovanja $t_{r}$ sistema $v-v$ može se analiticki izraziti obrascem:

$\mathrm{t}_{\mathrm{r}}=\mathrm{t}_{1}+\mathrm{t}_{2}+0,5 \cdot \mathrm{t}_{3}[\mathrm{~s}]$,

gde je:

$\mathrm{t}_{1}$ - vreme reagovanja (vreme sopstvene reakcije) vozaca [s], $\mathrm{t}_{2}$ - vreme zakašnjenja rada (vreme odziva) mehanizma za kocenje [s],

$\mathrm{t}_{3}$ - vreme porasta usporenja (vreme porasta pritiska) do punog kocenja [s].

Da bi se objasnilo reagovanje vozaca vršeni su brojni eksperimenti, koji nemaju prakticni znacaj, jer su izvodeni laboratorijski, u uslovima koji ne odgovaraju onima u saobracaju.

Pojavom auto-trenažera i filmskim simuliranjem saobracajnih situacija utvrdeno je, i u sudskoj praksi prihvaceno, da se za vreme reagovanja vozaca usvoji prosecno vreme $\mathrm{t}_{1}=0,8 \mathrm{~s}$.

U nekim izvorima [2] navodi se da se za prosecno (normativno) vreme reagovanja vozaca uzima $t_{1}=0,6 \mathrm{~s}(\mathrm{SR} \mathrm{Ne}-$ macka i Austrija). Kao vreme aktiviranja sistema za kocenje, u toku kojeg pritisak naraste do maksimuma $\left(t_{2}+0,5 t_{3}\right), u[2]$ se preporucuje za:

- putnicka vozila $0,2-0,3 \mathrm{~s}$,

- teretna vozila i autobuse $0,3-0,4 \mathrm{~s}$,

- vozila sa prikolicom i tegljace $0,5-1,0 \mathrm{~s}$,

- motocikle (sa rucnom kocnicom)

$0,1-0,2 \mathrm{~s}, \mathrm{i}$

- motocikle (sa nožnom kocnicom) $0,2-0,6 \mathrm{~s}$.

Prema tome, vreme reagovanja sistema v-v iznosi za:

- putnicka vozila .................... 0,8 s,

- teretna vozila i autobuse ...... 1,0 s,

- vozila sa prikolicom i tegljace 1,2 s i

- motocikle $0,7-0,8 \mathrm{~s}$

U praksi se cesto koriste izrazi ,psihicka sekunda", kao sinonim za vreme reagovanja vozaca, i ,psihotehnicka sekunda“, što podrazumeva vreme reagovanja sistema $\mathrm{v}-\mathrm{v}\left(\mathrm{t}_{1}+\mathrm{t}_{2}+0,5 \cdot \mathrm{t}_{3}\right)$ i za to se uzima $1,0 \mathrm{~s}$. 
Prema [3] normativno vreme reagovanja vozaca za normalne uslove u saobracaju iznosi 0,8 , a za složene i najsloženije uslove $1,0-1,5 \mathrm{~s}$. Normativno vreme reagovanja odnosi se na fiktivnog, prosecno obucenog, psihofizicki zdravog i sposobnog vozaca, koji osmatra situaciju na putu, prati i predvida razvoj dogadaja, da bi u slucaju opasnosti mogao da reaguje. Iz ovih izvora $[3,2]$ vidi se da je normativno vreme reagovanja vozaca-sistema $\mathrm{v}-\mathrm{v}$ razlicito. Dakle, to je predmet konvencije, a ne preciznog definisanja $\mathrm{i}$ razgranicenja ovih pojmova.

\section{Merenje realnog vremena reagovanja vojnika vozaca}

Da bi odredili vreme reagovanja vozaca-sistema $\mathrm{v}-\mathrm{v}^{2}$ izveden je eksperiment u realnim uslovima [4] sa 39 slucajno odabranih vojnika vozaca.

Za merenje vremena reagovanja vozaca, prema definisanim uslovima, razvijen je poseban sistem (merni uredaj ${ }^{3}$ ), koji se sastoji od modula za merenje vremenskog intervala sa rezolucijom od 1 ms i sistema za akviziciju i prikazivanje podataka [5] (sl. 1).

\section{Uslovi koje treba da zadovolji merni uredaj}

Za merenje vremena reagovanja vozaca angažovana su dva vozila TAM5000. To su vojna vozila, sa specificnim rešenjem svetlosne signalizacije i hidro-

\footnotetext{
${ }^{2}$ Pod pojmom ,reagovanje vozaca“ $u$ ovom radu podrazumeva se „reagovanje sistema $\mathrm{V}-\mathrm{v}^{\prime \prime}$.

${ }^{3}$ Ure daj za merenje vremena reagovanja razvio je konstruisao Siniša Durutovic u privatnoj uslužnoj radnji „DigiSoft" Kraljevo www.DigiSoft.co.yu.
}

pneumatskim sistemom kocenja. Radi navedenih specificnosti i opštih tehnickih zahteva, merni uredaj treba da bude [4]:

- prenosan, pogodnih (malih) dimenzija, jednostavan i lak za prikljucivanje;

- otporan na vibracije, visoke temperature i pogodan za rad na terenu;

- otporan na varnicenje na kontaktima i na radio-smetnje elektro uredaja na vozilu;

- otporan na uticaj radio-signala i drugih izvora zracenja iz okoline;

- zašticen u slucaju pogrešnog prikljucivanja na elektro instalaciju vozila.

Pored toga, treba da omoguci vizuelnu kontrolu merenja po fazama i kontrolu ispravnosti uredaja.

Tehnicki uslovi obezbedeni su konstrukcijom, izborom i ugradnjom hardverskih komponenti. Ove karakteristike su konstantne, jer se naknadno ne mogu menjati [5].

Algoritam i softver za merenje vremena reagovanja morao je da ispunjava neke specificne uslove [5], kao što su:

- rad (merenje) u realnom vremenu;

- prepoznavanje i selekcija vremena reagovanja na osnovu redosleda kocenja vozila;

- pouzdanost pri merenju i veliki broj autonomnih merenja;

- cuvanje i zaštita podataka bez napajanja i pražnjenja na nadredeni sistem;

- mogucnost identifikacije vozaca i raspoznavanje podataka svakog vozaca, $i$

- transparentno i jednostavno prikazivanje podataka.

Za razliku od hardverskih, softverske karakteristike uredaja, pored laboratorijskog ispitivanja, proveravane su, i u izvesnom smislu dogradivane i prilagodavane nameni, i u radu. 


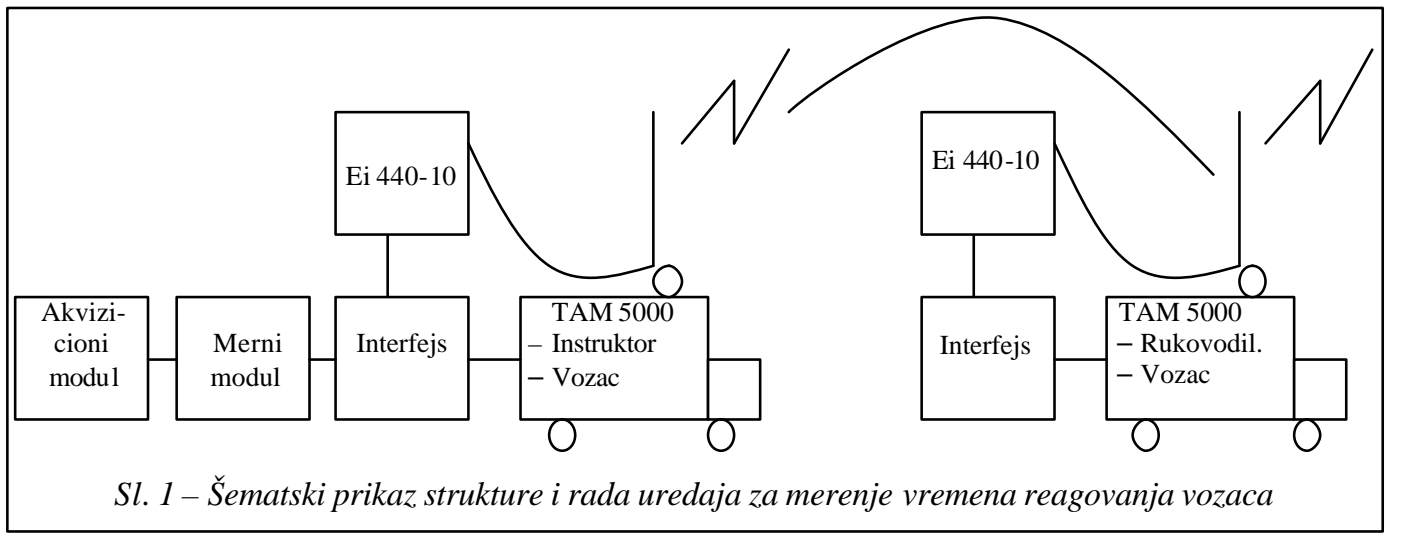

Sva izmerena vremena manja od $0,4 \mathrm{~s}$ smatrana su nevažećim ${ }^{4}$ i nisu slata sistemu za akviziciju podataka. Merni modul morao je da uzme u obzir samo ispravan sled dogadaja pri kocenju. Pritiskanje kocnice prvog vozila, koje vrši vozac, pa zatim pritiskanje kocnice drugog vozila koje obavlja vozac kome se meri vreme reagovanja jedini su ispravni sled dogadaja. Višestruko pritiskanje pedale za vreme kocenja jednog vozaca i razna druga neregularna stanja merni modul je trebalo da prepozna i da sistemu za akviziciju pošalje samo ispravna vremena reagovanja vozaca. Takode, novo merenje nije smelo poceti sve dok oba vozaca nisu otpustila pedalu kocnice. Merni modul trebalo je da obezbedi svetlo snu indikaciju za: aktiviranje kocnice u prvom vozilu, aktiviranje kocnice na drugom vozilu, pocetak i završetak procesa merenja. Ovakva signalizacija trebalo je da omoguci vizuelnu kontrolu ispravnosti celog procesa $\mathrm{u}$ toku merenja vremena reagovanja. To se u praksi pokazalo korisnim, radi provere ispravnosti komunikacionog kanala i pojedinih komponenti mernog uredaja.

\footnotetext{
${ }^{4}$ Vremena manja od ovog su zanemarena, jer se smatra da je to minimalna vrednost koja se u praksi ostvaruje.
}

Vozila na kojima su vršena merenja poseduju hidro-pneumatski sistem kocenja, pa je na pedali kocnice bila potrebna veca sila od uobicajene da bi se aktivirala svetlosna signalizacija. Na to je, pri merenju, instruktor ukazivao vozacu drugog vozila, prateci svetlosnu signalizaciju na prvom vozilu i na mernom modulu. Specificna konstrukcija signalizacije na vojnim vozilima objedinjava stop-svetla i pokazivace pravca (migavce). Pri ukljucivanju pokazivaca pravca blokira se stop-svetlo, pa ga pri merenju merni modul nije mogao prepoznati. Zbog toga se u toku merenja nisu smeli koristiti pokazivaci pravca.

Merna oprema radila je u veoma teškim terenskim uslovima, izložena visokim temperaturama i vibracijama. Kvar na komunikacionom kanalu mogao je lako da se uoci prestankom prenosa signalizacije. Eventualni kvarovi, u toku rada, brzo i lako su dijagnostikovani, bez posebnog alata i merne opreme.

\section{Princip rada uredaja za merenje vremena reagovanja sistema}

Kada vozac u prvom vozilu pritisne pedalu kocnice poraste pritisak u sistemu za kocenje i aktivira se stop-svetlo. Inter- 
fejs u prvom vozilu (sl. 1) generiše signal od $1700 \mathrm{~Hz}$, koji se govornim kanalom, od stanice u prvom vozilu prenosi do stanice u drugom vozilu. Interfejs u drugom vozilu (sl. 1) ima zadatak da taj analogni signal od $1700 \mathrm{~Hz}$ pretvori u pogodan diskretni signal, koji prihvata merni modul. Kada merni modul prihvati diskretni signal tada otpocinje merenje vremena reagovanja.

Kada vozac u drugom vozilu uoci stop-svetlo prvog vozila i aktivira kocnicu, aktiviraju se stop-svetla drugog vozila i preko interfejsa u drugom vozilu (sl. 1) signal se direktno prenosi mernom modulu. Kada merni modul primi taj signal prekida se merenje vremena.

Izmereno vreme se od mernog modula, posredstvom RS232 interfejsa, prosleduje akvizicionom modulu (sl. 1), koji pamti podatke, formira bazu podataka i na displeju prikazuje tekuce (zadnje) vreme reagovanja sa pripadajucim atributima: ID kandidata, datum merenja, vreme merenja i vreme reagovanja, npr. (30 25.07.2002 10:26:08 2.986).

\section{Organizacija i realizacija merenja vremena reagovanja sistema}

Merenje vremena reagovanja sistema $\mathrm{v}-\mathrm{v}$ izvedeno je $\mathrm{u}$ realnim uslovima. $\mathrm{Za}$ merenje je formiran reprezentativni uzorak od 39 slucajno odabranih vojnika vozaca. Merenje je organizovao i rukovodio eksperimentom „rukovodilac merenja“, koji se u toku rada nalazio u prvom - vodecem vozilu. Pre pocetka merenja on je definisao uslove rada, formirao reprezentativni uzorak, definisao softverske i tehnicke zahteve rada uredaja za merenje vremena reagovanja. U toku merenja ru- kovodilac je kontrolisao uslove rada, postavljao zahteve vozacu vodeceg vozila $i$ režirao situacije za reagovanje vozaca kome se meri vreme reagovanja.

U realizaciji eksperimenta rukovodiocu merenja pomagao je ,instruktor merenja“, koji se nalazio u drugom vozilu sa vozacem kome se meri vreme reagovanja. U probnoj fazi eksperimenta on je imao zadatak da izvrši proveru i verifikaciju softvera, uoci i otkrije nje gove nedostatke, da ga koriguje i prilagodi nameni. ${ }^{5} \mathrm{U}$ toku merenja vremena reagovanja instruktor je, preko alfanumericke tastature terminala na akvizicionom modulu, unosio ID brojeve vozaca, davao im instrukcije i pratio njihov rad, vizuelno kontrolisao zapis na displeju, a preko indikatorskih lampica rad komunikacionog kanala $\mathrm{i}$ ispravnost uredaja.

Pri formiranju reprezentativnog uzorka vozacima su dodeljeni ID brojevi, koje je trebalo da pamte, $i$ da ih pri ulasku u vozilo saopšte instruktoru. U toku merenja vremena reagovanja vozaci su imali zadatak da vozilom upravljaju zadatom brzinom, a vozac drugog vozila trebalo je da sledi prvo, na zadatom rastojanju, koje je on odredivao po slobodnoj proceni. Kada vozac u prvom vozilu pritisne pedalu kocnice i aktivira stop-svetla, vozac u drugom vozilu imao je zadatak da prikoci, radi održa vanja odstojanja. Sistem za merenje vremena reagovanja imao je zadatak da izmeri vremenski interval od ukljucivanja stop-svetla na prvom vozilu do aktiviranja kocionog sistema na drugom vozilu.

\footnotetext{
${ }^{5}$ Instruktor merenja bio je konstruktor uredaja za merenje vremena reagovanja vozaca. Pre pocetka merenja on je kreirao softver i laboratorijski ispitao uredaj.
} 
Prema [3], zbog velikog broja relevantnih faktora, interval reagovanja vozaca kocenjem dosta je širok i iznosi 0,4 do $1,5 \mathrm{~s}$. Radi provere, gde se u ovom intervalu nalaze pojedini vozaci reprezentativnog uzorka mereno je vreme reagovanja za unapred odredene uslove ${ }^{6}$ (tab. 2, kolone 2-6), koji su tokom eksperimenta kontrolisani [5].

Vreme je registrovano digitalnim elektronskim tajmerom, sa tacnošcu od \pm 1 milisekund, koji je uklju civan i iskljucivan automatski, radio-signalom. $\mathrm{Za}$ razliku od ranijih merenja, koja su vršena automatizovano, uz posredovanje coveka izmedu mernog i komandnog uredaja, ovde je jedini zadatak coveka u ulozi vozaca-ispitanika bio da pritiskom pedale kocnice preko stop-svetla iskljuci casovnik, koji je, pri nailasku na prepreku ukljucio vozac vodeceg vozila - „lidera“, kako ga naziva Lobanov [1]. Vreme reagovanja vozaca registrovano je automatski u mikroprocesoru, kao interval izmedu ukljucivanja stop-svetala na prvom i drugom v?zilu, a kasnije je radi obrade preneto na racunar.

Uslovi pod kojima su izvedena merenja [5]: davina;

- dan, vreme promenljivo, bez pa-

- kolovoz asfaltni za dvosmerni saobracaj, širine $7 \mathrm{~m}$, dobrog kvaliteta;

- intenzitet saobracaja mali 300400 voz./h;

- starost vozaca od 20 do 27,5 godina, sa nominalnim vozackim stažom od 0,75 do 8 godina [9] (str. 119, tab. 4.4, kolone 3 i 4);

\footnotetext{
${ }^{6}$ Uslovi se odnose na brzi nu i odstojanje izmedu vozila $\mathrm{u}$ toku kretanja i vreme vožnje - opterecenje (vreme vožnje $[\mathrm{h}]$ / brzina $[\mathrm{km} / \mathrm{h}]$ / odstojanje $[\mathrm{m}])$.
}

- vozaci su proizvoljno procenili rastojanje do vodeceg vozila;

- broj merenja za pojedine uslove je razlicit, jer je reagovanje vozaca zavisilo od uslova i situacije u saobracaju.

\section{Analiza realnog vremena reago- vanja vojnika vozaca}

Najpotpunija analiza vremena reagovanja vozaca prikazana je u [1]. Parametri raspodele i intervali poverenja vremena reagovanja, $u$ zavisnosti od vremena vožnje (opterecenja), do kojih je došao prof. Lobanov, prikazani su u tab. 1. On je vreme reagovanja istraživao na vozacima, od 18 do 67 godina starosti, sa stažom upravljanja od 1 do 43 godine, pri cemu je izvršeno 2132 merenja vremena reagovanja, od cega je u 965 merenja signal bio ocekivan, a u 1167 neocekivan. ${ }^{7} \mathrm{U}[1]$ je utvrdeno da vreme reagovanja raste sa povecanjem brzine i odstojanja izmedu vozila, a da opada sa povecanjem vremena vožnje od 0 do $8 \mathrm{~h}$, a nakon toga raste (tab. 1). Pored toga, u [1] se istice da se vreme reagovanja povecava sa povecanjem intenziteta saobracaja, a da zavisi od starosti i staža upravljanja vozilom, jer mladi vozaci brže reaguju, a stariji brže odlucuju.

Pojedinacna vremena reagovanja vojnika vozaca nalaze se u širokom dijapazonu. Broj merenja pojedinih kandidata je razlicit, jer zavisi od okolnosti, uslova i ogranicenja u kojim je realizovan. Radi toga je potrebno da se podaci statisticki obrade, logicki analiziraju i uporede sa rezultatima prikazanim u [1].

\footnotetext{
Izvor [1], str. 167.
} 
Tabela 1 Parametri normalne raspodele i inter vali poverenja vremena reagovanja vozaca prema [1] za intenzitet saobracaja 100 do 300 voz./h

\begin{tabular}{|c|c|c|c|c|}
\hline $\begin{array}{c}\text { Dužina } \\
\text { vremena } \\
\text { vožnje } \\
\text { (opterece- } \\
\text { nje vozaca) } \\
\text { (h) }\end{array}$ & $\begin{array}{c}\text { Matematicko } \\
\text { ocekivanje } \\
\text { vremena } \\
\text { reagovanja } \\
\text { vozaca (s) }\end{array}$ & $\begin{array}{c}\text { Stan- } \\
\text { dardna } \\
\text { devijacija }\end{array}$ & $\begin{array}{c}\text { Verovat - } \\
\text { noca 95\% }\end{array}$ & $\begin{array}{c}\text { Verovat - } \\
\text { noca 99\% }\end{array}$ \\
\hline 0 & 1,39 & 0,173 & $1,39 \pm 0,35$ & $1,39 \pm 0,52$ \\
\hline 2 & 1,31 & 0,161 & $1,31 \pm 0,32$ & $1,31 \pm 0,48$ \\
\hline 4 & 1,21 & 0,135 & $1,21 \pm 0,27$ & $1,21 \pm 0,41$ \\
\hline 6 & 1,20 & 0,153 & $1,20 \pm 0,31$ & $1,20 \pm 0,46$ \\
\hline 8 & 1,29 & 0,210 & $1,29 \pm 0,42$ & $1,29 \pm 0,63$ \\
\hline 10 & 1,44 & 0,250 & $1,44 \pm 0,50$ & $1,44 \pm 0,75$ \\
\hline 12 & 1,53 & 0,272 & $1,53 \pm 0,54$ & $1,53 \pm 0,82$ \\
\hline
\end{tabular}

\section{Statisticka analiza realnog vremena reagovanja}

Analizom vremena reagovanja kocenjem [6] razmatramo vreme reagovanja sistema $v-v$, jer se vreme kocenja sastoji od vremena reagovanja vozaca i vozila, koja se u ovom radu posmatraju kao jedinstvena celina, ne ulazeci u njihovu strukturu.

U toku eksperimenta, vreme reagovanja sistema $\mathrm{v}-\mathrm{v}$ izmereno je 2889 puta za 39 vozaca. Eksperimentalni podaci, prema uslovima merenja, svrstani su u 5 grupa (tab. 2, kolone 2-6). Iz reprezentativnog uzorka apstrahovani su vozaci koji nisu završili sva merenja, pa je dobijen uporedni uzorak [6]. Statisticka obrada i analiza podataka izvršena je po grupama, uporedno ${ }^{8}$ i celovito za reprezentativni uzorak. Statisticki parametri vremena reagovanja sistema $\mathrm{v}-\mathrm{v}$ za uporedni uzorak prikazani su u tabeli 2 . Iz ovih podataka vidi se da je srednja vrednost vremena reagovanja veca, što je veca brzina i odstojanje (kolone 2, 3 i 4), a da se sa po-

\footnotetext{
${ }^{8} \mathrm{U}$ radu je pri kazana uporedna analiza za 30 vozaca (uporedni uzorak), koji su završili sva merenja.
}

vecanjem vremena vožnje vreme reagovanja smanjuje (kolone 3, 5 i 6 ), što je saglasno sa ranijim istraživanjima [1], gde se ukazuje da vreme reagovanja, zavisno od vremena vožnje, opada od 0 do $8 \mathrm{~h}$, a nakon toga raste ${ }^{9}$ (tab. 1).

Analizom statistickih parametara vremena reagovanja sistema $\mathrm{v}-\mathrm{v}$, za uporedni uzorak (tab. 2), za sve uslove utvrdeno je [6] da se raspodela srednjih vrednosti vremena reagovanja vozaca slaže sa Gausovom (normalnom) raspodelom (sl. 2), što je potvrdeno ?2 (hi-kvadrat) testom, sa rizikom prihvatanja hipoteze o saglasnosti empirijske i teorijske raspodele od 0,01 . Test ? ${ }^{2}$ pokazuje da postoji visoka verovatnoca da su srednje vrednosti realnog vremena reagovanja svih vojnika vozaca $\mathrm{s}$ normalnom raspodelom verovatnoca i da su odstupanja od ove raspodele sasvim slucajna. Poligon empirijske raspodele srednjeg kumulativnog vremena reagovanja za uporedni uzorak i teorijska raspodela prikazani su na sl. 2, a parametri raspodele $\mathrm{i}$ intervali poverenja na sl. 2. i tab. 3.

$\mathrm{Na}$ osnovu dobijenih rezultata i uporedne statisticke analize, za vozace koji su završili sva merenja odredeni su intervali poverenja vremena reagovanja za sve uslove [6] (tab. 3). Ovi podaci predstavljaju osnovu za odredivanje realnog vremena reagovanja sistema $\mathrm{v}-\mathrm{v}$. U konkretnoj situaciji, zavisno od psihofizickog stanja vozaca, karakteristika i stanja vozila i objektivnog stanja puta i okoline, može se odrediti vreme reagovanja sistema $\mathrm{v}-\mathrm{v}$ iz intervala poverenja (tab. 3) za date uslove. Iz podataka u [6] (tab. 3) vi-

${ }^{9} \mathrm{U}$ ovom istraživanju analiza je vršena od 0 do $5 \mathrm{~h}$ vožnje - rada, u tri koraka. 


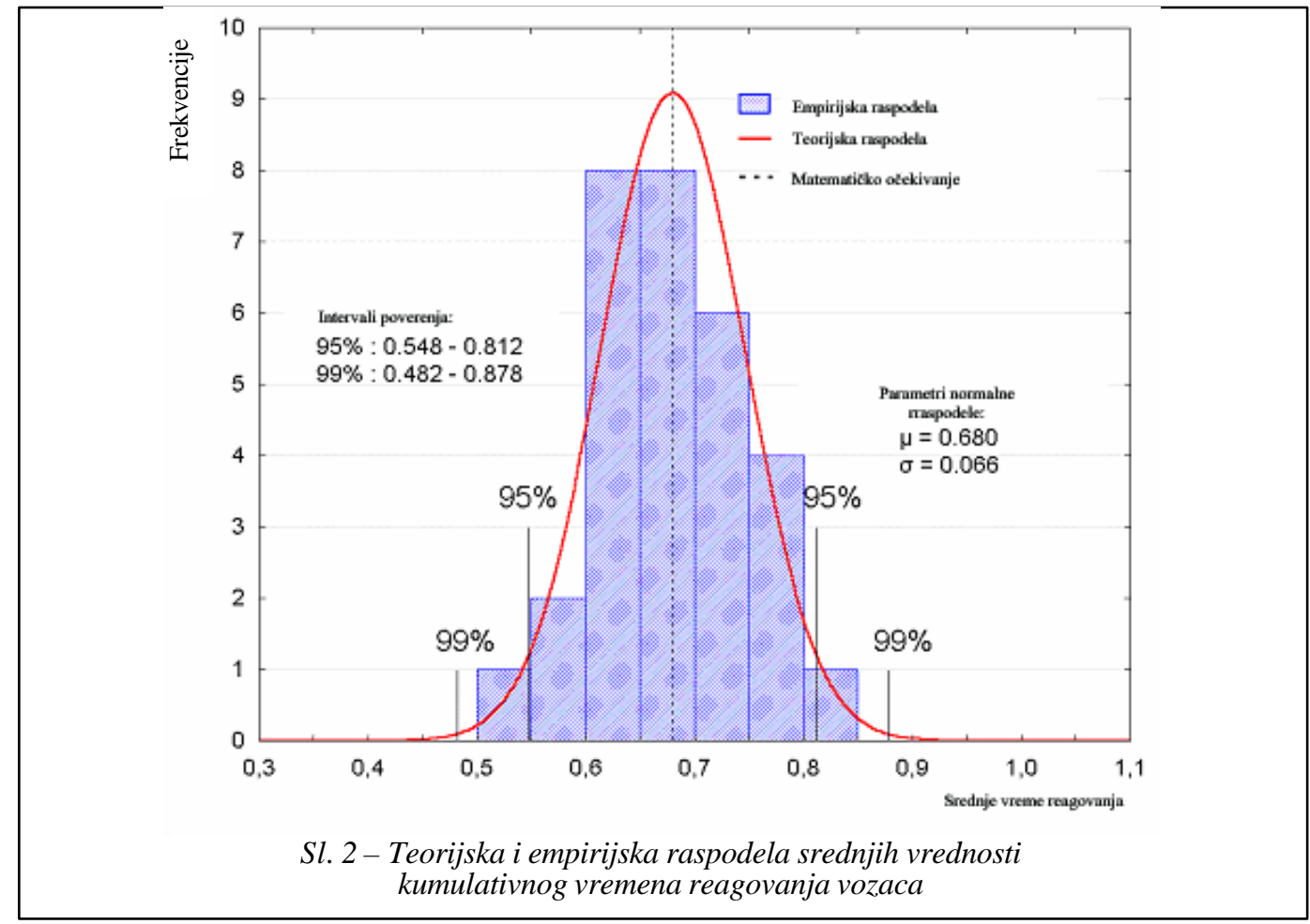

di se da se ova vremena znatno razlikuju od vremena reagovanja vozaca prikazanog u [1] (tab. 1) i normativnog vremena reagovanja vozaca.

Analizom koeficijenta korelacije $^{10}$ prema uslovima merenja, uoceno je da je razlika srednjih vrednosti vremena reagovanja vozaca za razlicite brzine i odstojanja statisticki znacajna, odnosno da nije slucajna, što se ne može reci za razlicita opterecenja u toku vožnje.

\section{Logicka analiza realnog vremena reagovanja}

Istraživaci su, u brojnim istraživanjima, nastojali da se vreme reagovanja sistema $\mathrm{v}-\mathrm{v}$ definiše i odredi njegov uticaj na bezbednost saobracaja, a uticaj na

\footnotetext{
${ }^{10}$ Zbog obima rada, koeficijenti korelacije se ne pri ka-
} zuju, već se komentarišu. upravljanje i efikasnost kretanja je zanemarivan, pa to nije rasvetlje no ni teorijski ni prakticno. Dometi ovih istraživanja bili su ograniceni, jer su vršena laboratorijski, a ne u realnim uslovima. U [7] se istice da je ovaj parametar, po uticaju na efikasnost i bezbednost saobracaja, drugi po znacaju, odmah iza brzine.

U praksi se, umesto realnog vremena reagovanja vozaca, koristi normativno vreme reagovanja i uzima se da je ono $1,0 \mathrm{~s},{ }^{11}$ ali se ne navode njegovi statisticki parametri, pa je otežan analiticki pristup problemima bezbednosti i upravljanja kretanjem, sa ovog aspekta. Normativno vreme reagovanja gruba je i relativizirana kvantitativna i kvalitativna mera reakcije vozaca automobila, jer se odnosi na fiktivne uslo-

${ }^{11} \mathrm{U}$ literaturi se koriste izrazi ,psihiča sekunda“ $i$,,psihotehnička sekunda" kao sinonimi za reagovanje vozača i sistema v-v. 
Statisticki parametri vremena reagovanja sistema $v-v$ za uporedni uzorak

\begin{tabular}{|l|c|c|c|c|c|c|}
\hline \multirow{3}{*}{ Statisticki parametri } & \multicolumn{5}{|c|}{ Uslovi merenja vremena reagovanja sistema v-v } & \multirow{2}{*}{$\begin{array}{c}\text { Kumulativno } \\
\text { vreme }\end{array}$} \\
\cline { 2 - 3 } & $45 \mathrm{~km} / \mathrm{h}$ & $60 \mathrm{~km} / \mathrm{h}$ & $75 \mathrm{~km} / \mathrm{h}$ & $2 \mathrm{~h}$ & $5 \mathrm{~h}$ & \\
\cline { 5 - 6 } & $30 \mathrm{~m}$ & $50 \mathrm{~m}$ & $100 \mathrm{~m}$ & $60 \mathrm{~km} / \mathrm{h} / 50 \mathrm{~m}$ & $60 \mathrm{~km} / \mathrm{h} / 50 \mathrm{~m}$ & reagovanja s \\
\hline \multicolumn{1}{|c}{1} & 2 & 3 & 4 & 5 & 6 & 7 \\
\hline Srednja vrednost & 0,639 & 0,697 & 0,728 & 0,677 & 0,659 & 0,680 \\
\hline Standardna devijacija & 0,093 & 0,196 & 0,123 & 0,102 & 0,101 & 0,066 \\
\hline Varijansa & 0,009 & 0,039 & 0,015 & 0,010 & 0,010 & 0,004 \\
\hline Koeficijent varijanse & 14,49 & 28,16 & 16,95 & 15,09 & 15,26 & 9,67 \\
\hline Maksimalna vrednost & 0,946 & 1,486 & 1,006 & 0,889 & 0,949 & 0,826 \\
\hline Minimalna vrednost & 0,514 & 0,486 & 0,497 & 0,484 & 0,558 & 0,531 \\
\hline Raspon & 0,432 & 1,000 & 0,509 & 0,405 & 0,391 & 0,295 \\
\hline Medijana & 0,616 & 0,662 & 0,723 & 0,683 & 0,635 & 0,688 \\
\hline Moda & 0,594 & 0,754 & 0,653 & 0,574 & 0,670 & 0,647 \\
\hline Broj merenja & 728 & 543 & 345 & 435 & 445 & 2496 \\
\hline Broj kandidata & 30 & 30 & 30 & 30 & 30 & 30 \\
\hline Merenja po kandidatu & 24,27 & 18,10 & 11,50 & 14,50 & 14,83 & 83,20 \\
\hline
\end{tabular}

Tabela 3

Parametri normalne raspodele i intervali poverenja vremena reagovanja za uporedni uzorak i sve uslove merenja

\begin{tabular}{|c|c|c|c|c|}
\hline \multirow{2}{*}{$\begin{array}{c}\text { Uslovi merenja vremena } \\
\text { reagovanja (vreme vožnje, } \\
\text { brzina, odstojanje) }\end{array}$} & \multirow{2}{*}{$\begin{array}{c}\text { Matematicko ocekivanje } \\
\text { vremena reagovanja } \\
\text { vozaca s }\end{array}$} & \multirow{2}{*}{$\begin{array}{c}\text { Standardna } \\
\text { devijacija }\end{array}$} & \multicolumn{2}{|c|}{ Intervali poverenja za $t_{r}$} \\
\hline & & & $\begin{array}{c}\text { Verovatnoca } \\
95 \% \\
\end{array}$ & $\begin{array}{c}\text { Verovatnoca } \\
99 \%\end{array}$ \\
\hline $45 \mathrm{~km} / \mathrm{h}-30 \mathrm{~m}$ & 0,639 & 0,093 & $0,639 \pm 0,185$ & $0,639 \pm 0,278$ \\
\hline $60 \mathrm{~km} / \mathrm{h}-50 \mathrm{~m}$ & 0,697 & 0,196 & $0,697 \pm 0,393$ & $0,697 \pm 0,589$ \\
\hline $75 \mathrm{~km} / \mathrm{h}-100 \mathrm{~m}$ & 0,728 & 0,123 & $0,728 \pm 0,247$ & $0,728 \pm 0,370$ \\
\hline $2 \mathrm{~h}-60 \mathrm{~km} / \mathrm{h}-50 \mathrm{~m}$ & 0,677 & 0,102 & $0,677 \pm 0,204$ & $0,677 \pm 0,307$ \\
\hline $5 \mathrm{~h}-60 \mathrm{~km} / \mathrm{h}-50 \mathrm{~m}$ & 0,659 & 0,101 & $0,659 \pm 0,201$ & $0,659 \pm 0,302$ \\
\hline Kumulativno srednje $t_{r}$ & 0,680 & 0,066 & $0,680 \pm 0,132$ & $0,680 \pm 0,198$ \\
\hline
\end{tabular}

ve i prosecno obucenog vozaca. Radi toga ga treba koristiti kriticki i obazrivo, primereno psihofizickom stanju vozaca, konkretnim uslovima saobracaja, puta, okoline i drugim objektivnim okohnostima. Nekriticko korišcenje normativnog vremena reagovanja neminovno vodi u zabludu i pogrešno zakljucivanje, cije posledice mogu biti ozbiljne.

Prethodna istraživanja vremena reagovanja upucuju na analizu zavisnosti vremena reagovanja vojnika vozaca od iskustva, starosti i staža vozaca i sagledavanje povezanosti ovih obeležja i vremena reagovanja.
Obeležja iskustva su: staž upravljanja vozilom, starost-uzrast vozaca i ucestalost upravljanja vozilom (tab. 4). U uporednom uzorku bilo je 13 kandidata $^{12}$ koji su svakodnevno upravljali $\mathrm{m} / \mathrm{v}, 17$ povremeno, a dva su bili autoprevoznici [9] (str. 119, tab. 4.4, kolona 2).

Vreme reagovanja uporednog uzorka, prema ovim obeležjima, prikazano je u tabeli 4. Analizom srednjih vrednosti vremena reagovanja za pojedine uslove

${ }^{12} \mathrm{U}$ ovu grupu uključena su dva autoprevoznika, ali su prikazani i izdvojeno, kao profesionalni vozači, radi poređenja sa ostalim grupama uzorka. 
Vreme reagovanja vozaca prema iskustvu za uporedni uzorak $i$ sve uslove merenja

\begin{tabular}{|c|c|c|c|c|c|c|c|c|}
\hline \multicolumn{3}{|c|}{ Obeležja iskustva vozaca } & \multicolumn{5}{|c|}{ Uslovi merenja vremena reagovanja sistema $\mathrm{v}-\mathrm{v}$} & \multirow[b]{2}{*}{$\begin{array}{c}\text { Kumula- } \\
\text { tivno } \\
\text { srednje } \\
\text { vreme }\end{array}$} \\
\hline $\begin{array}{c}\text { Ucestalost } \\
\text { upravljanja vozilom }\end{array}$ & 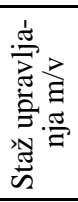 & 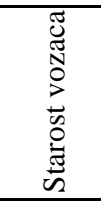 & $\begin{array}{l}45 \mathrm{~km} / \mathrm{h} \\
30 \mathrm{~m}\end{array}$ & $\begin{array}{l}60 \mathrm{~km} / \mathrm{h} \\
50 \mathrm{~m}\end{array}$ & $\begin{array}{c}75 \mathrm{~km} / \mathrm{h} \\
100 \mathrm{~m}\end{array}$ & $\begin{array}{c}2 \mathrm{~h} \\
60 \mathrm{~km} / \mathrm{h} \\
50 \mathrm{~m}\end{array}$ & $\begin{array}{c}5 \mathrm{~h} \\
60 \mathrm{~km} / \mathrm{h} \\
50 \mathrm{~m}\end{array}$ & \\
\hline 1 & 2 & 3 & 4 & 5 & 6 & 7 & 8 & 9 \\
\hline Svakodnevno & 3,91 & 22,510 & 0,658 & 0,714 & 0,717 & 0,693 & 0,655 & 0,686 \\
\hline Povremeno & 3,68 & 22,050 & 0,629 & 0,685 & 0,736 & 0,665 & 0,661 & 0,675 \\
\hline Autoprevoznici & 2,67 & 21,331 & 0,585 & 1,020 & 0,665 & 0,716 & 0,628 & 0,722 \\
\hline Uporedni uzorak & 3,78 & 23,303 & 0,639 & 0,697 & 0,728 & 0,677 & 0,659 & 0,680 \\
\hline
\end{tabular}

merenja može se uociti da se prema svim obeležjima vreme reagovanja povecava sa usložavanjem uslova (povecanjem brzine i odstojanja) (tab. 4, kolone 4, 5 i 6). Izuzetak su autoprevoznici, kojih je bilo samo dva, od kojih je vozac broj 5 imao samo dva uspešna merenja vremena reagovanja, za uslove u koloni 5 (tab. 4), pri cemu je jedno merenje iznosilo $2,387 \mathrm{~s}$, pa je zato srednja vrednost vremena reagovanja za ovaj uslov relativno velika. Ako se povecava vreme vožnje (opterecenje) od 0 do $5 \mathrm{~h}$ vreme reagovanja opada za sve tri grupe (tab. 4, kolone 5, 7 i 8), kao i u [1].

Povezanost realnog vremena reagovanja $i$ iskustva vojnika vozaca može se oceniti analizom koeficijenata korelacije $[8,9]$ izmedu staža $i$ starosti vozaca $i$ vremena reagovanja. ${ }^{13}$ Uocava se [9] da je sa povecanjem staža i starosti vozaca promena vremena reagovanja neznatna. To znaci da je korelacija izmedu ovih parametara niska, a povezanost mala. ${ }^{14}$ Ipak, zapaža se da vreme reagovanja vojnika vozaca više zavisi od starosti nego od staža vozaca.

\footnotetext{
${ }^{13}$ Izvor [9], stranica 124.

${ }^{14}$ Možda bi korelativna veza bila jača da su starost $i$ staž vozača veći (da su u šrem intervalu, kao u [1]).
}

Analizom vremena reagovanja uporednog uzorka [6] može se zapaziti da se ono razlikuje za pojedine uslove (tab. 2. i 3). Analizom rezultata reprezentativnog uzorka uocava se da vreme reagovanja zavisi od starosti i staža vozaca [9]. Ako se uporedni uzorak podeli na dve grupe, prema dužini vozackog staža ${ }^{15}$ (tab. 5), može se zapaziti da je srednja vrednost staža prve grupe 4,93 godine, a srednje kumulativno vreme reagovanja $0,660 \mathrm{~s}$. Prosecan vozacki staž druge grupe je 2,62 godine, a srednje kumulativno vreme reagovanja $0,700 \mathrm{~s}$. Dakle, srednje vreme reagovanja druge grupe, ciji je staž znatno manji (tab. 5), vece je za $0,040 \mathrm{~s}$.

Do slicnog zakljucka može se doci analizom realnog vremena reagovanja prema starosti vozaca ${ }^{16}[9]$ (str. 126, tab. 4.11). Ako se uporedni uzorak podeli na dve grupe, prema starosti vozaca, prosecna starost prve grupe je 23,303 godina, a pripadajuce srednje vreme reagovanja 0,668 s. Prosecna starost druge grupe je 21,196 godina, a srednje vreme reagovanja 0,692 s. Prema tome, srednje vreme reagovanja mlade grupe vozaca vece je za $0,025 \mathrm{~s}$. Do istih

${ }^{15}$ Odnosi se na nominalni vozački staž, od polaganja vozačkog ispita do završetka eksperimenta.

${ }_{16}$ Starost uporednog uzorka bila je u intervalu 20 do 27,5 godina, a nominalni vozački staž od 1 do 8 godina. 
Srednje vreme reagovanja sistema v-v prema vozackom stažu za uporedni uzorak

\begin{tabular}{|c|c|c|c|c|c|c|c|c|}
\hline \multirow{2}{*}{$\begin{array}{l}\overline{0} \\
0 \\
\dot{0} \\
\mathscr{0}\end{array}$} & \multirow{2}{*}{ 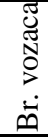 } & \multirow[b]{2}{*}{$\begin{array}{l}\text { Staž uprav } \\
\text { ljanja m/v }\end{array}$} & \multicolumn{5}{|c|}{ Uslovi merenja vremena reagovanja sistema v-v } & \multirow{2}{*}{$\begin{array}{c}\text { Kumulativno } \\
\text { srednje } \\
\text { vreme }\end{array}$} \\
\hline & & & $\begin{array}{c}45 \mathrm{~km} / \mathrm{h} \\
30 \mathrm{~m}\end{array}$ & $\begin{array}{c}60 \mathrm{~km} / \mathrm{h} \\
50 \mathrm{~m}\end{array}$ & $\begin{array}{c}75 \mathrm{~km} / \mathrm{h} \\
100 \mathrm{~m}\end{array}$ & $\begin{array}{c}2 \mathrm{~h} \\
60 \mathrm{~km} / \mathrm{h} \\
50 \mathrm{~m}\end{array}$ & $\begin{array}{c}5 \mathrm{~h} \\
60 \mathrm{~km} / \mathrm{h} \\
50 \mathrm{~m}\end{array}$ & \\
\hline 1 & 2 & 3 & 4 & 5 & 6 & 7 & 8 & 9 \\
\hline 1 & 38 & 8,17 & 0,826 & 0,891 & 0,653 & 0,802 & 0,600 & 0,754 \\
\hline 2 & 25 & 7,17 & 0,652 & 0,754 & 0,755 & 0,711 & 0,602 & 0,695 \\
\hline 3 & 35 & 5,83 & 0,631 & 0,666 & 0,710 & 0,797 & 0,649 & 0,691 \\
\hline 4 & 36 & 5,67 & 0,594 & 0,775 & 1,006 & 0,543 & 0,587 & 0,701 \\
\hline 5 & 37 & 5,33 & 0,603 & 0,754 & 0,818 & 0,698 & 0,585 & 0,692 \\
\hline 6 & 30 & 5,17 & 0,563 & 0,569 & 0,964 & 0,574 & 0,563 & 0,647 \\
\hline 7 & 6 & 5,08 & 0,550 & 0,527 & 0,549 & 0,587 & 0,670 & 0,577 \\
\hline 8 & 18 & 4,92 & 0,591 & 0,571 & 0,900 & 0,716 & 0,667 & 0,689 \\
\hline 9 & 17 & 4,50 & 0,558 & 0,584 & 0,618 & 0,889 & 0,785 & 0,687 \\
\hline 10 & 29 & 4,25 & 0,581 & 0,670 & 0,632 & 0,526 & 0,56 & 0,594 \\
\hline 11 & 15 & 4,08 & 0,635 & 0,550 & 0,802 & 0,678 & 0,607 & 0,654 \\
\hline 12 & 16 & 3,58 & 0,594 & 0,714 & 0,497 & 0,699 & 0,560 & 0,613 \\
\hline 13 & 24 & 3,42 & 0,52 & 0,486 & 0,572 & 0,484 & 0,591 & 0,531 \\
\hline 14 & 21 & 3,42 & 0,627 & 0,724 & 0,653 & 0,714 & 0,873 & 0,718 \\
\hline 15 & 32 & 3,42 & 0,673 & 0,720 & 0,685 & 0,574 & 0,648 & 0,660 \\
\hline \multicolumn{2}{|c|}{ prosek } & 4,93 & 0,613 & 0,664 & 0,721 & 0,666 & 0,636 & 0,660 \\
\hline 16 & 3 & 3,42 & 0,614 & 0,550 & 0,589 & 0,688 & 0,568 & 0,602 \\
\hline 17 & 27 & 3,42 & 0,728 & 0,771 & 0,737 & 0,674 & 0,620 & 0,706 \\
\hline 18 & 9 & 3,25 & 0,618 & 0,539 & 0,784 & 0,639 & 0,654 & 0,647 \\
\hline 19 & 31 & 3,00 & 0,736 & 0,806 & 0,798 & 0,770 & 0,638 & 0,750 \\
\hline 20 & 4 & 3,00 & 0,612 & 0,994 & 0,898 & 0,664 & 0,627 & 0,759 \\
\hline 21 & 19 & 2,83 & 0,946 & 0,711 & 0,707 & 0,754 & 0,627 & 0,749 \\
\hline 22 & 20 & 2,75 & 0,716 & 0,587 & 0,745 & 0,551 & 0,632 & 0,646 \\
\hline 23 & 5 & 2,75 & 0,655 & 1,486 & 0,669 & 0,625 & 0,697 & 0,826 \\
\hline 24 & 26 & 2,75 & 0,603 & 0,658 & 0,735 & 0,814 & 0,949 & 0,752 \\
\hline 25 & 12 & 2,58 & 0,514 & 0,553 & 0,660 & 0,806 & 0,558 & 0,618 \\
\hline 26 & 34 & 2,42 & 0,582 & 0,538 & 0,626 & 0,534 & 0,915 & 0,639 \\
\hline 27 & 14 & 2,42 & 0,649 & 0,604 & 0,809 & 0,626 & 0,703 & 0,678 \\
\hline 28 & 10 & 2,25 & 0,758 & 0,597 & 0,882 & 0,638 & 0,663 & 0,708 \\
\hline 29 & 8 & 1,58 & 0,542 & 0,617 & 0,616 & 0,727 & 0,670 & 0,634 \\
\hline 30 & 39 & 0,92 & 0,696 & 0,951 & 0,769 & 0,812 & 0,690 & 0,784 \\
\hline \multicolumn{2}{|c|}{ prosek } & 2,62 & 0,665 & 0,731 & 0,735 & 0,688 & 0,681 & 0,700 \\
\hline
\end{tabular}

zakljucaka dolazimo analizom vremena reagovanja, prema ovim atributima uporednog uzorka za sve uslove i grupe (tab. 5, kolone 4-8). Ovi rezultati saglasni su sa ranijim istraživanjima [1].

Poredenjem kumulativnog vremena reagovanja, sa parcijalnim i pojedinac- nim vremenima (tab. 5), uocava se da je maksimalno kumulativno vreme reagovanja $0,826 \mathrm{~s}$, a ostvario ga je vozac broj 5 , profesionalac-autoprevoznik. Minimalno srednje kumulativno vreme $0,531 \mathrm{~s}$ imao je vozac broj 24, koji povremeno upravlja vozilom (tab. 5). Srednje kumulativ- 
no vreme uporednog uzorka (tab. 2) iznosilo je 0,680 s. Parcijalna vremena reagovanja su analogna ovim vrednostima, a pojedinacna se znatno razlikuju. Pregled ekstremnih pojedinacnih vremena reagovanja, prema uslovima merenja, prikazan je u tabeli 6. Analizom ekstremnih vrednosti vremena reagovanja (tab. 6), vidi se da su sva ekstremna vremena reagovanja ostvarili razliciti vozaci. To znaci da nema vozaca sklonih ,velikim“ ili „malim“ vremenima reagovanja, pa se može zakljuciti da vreme reagovanja ne zavisi samo od subjektivnih osobina vozaca. U principu, vozaci koji imaju manja pojedinacna vremena reagovanja imaju i srednje vreme reagovanja manje, ali to nije pravilo i ne odnosi se na sve vozace $i$ uslove. Maksimalno pojedinacno vreme reagovanja uporednog uzorka je 2,986 (tab. 6), a ostvario ga je vozac broj 30 , pri brzini od $75 \mathrm{~km} / \mathrm{h}$ i odstojanju $100 \mathrm{~m}$, cije je srednje kumulativno vreme $0,647 \mathrm{~s}$, znatno manje od proseka uporednog uzorka (tab. 5. i 2).

Minimalno vreme reagovanja $0,400 \mathrm{~s}$ ostvarili su vozaci br. 3 i 24 (tab. 6). To- kom merenja vremena reagovanja uoceno je da su pojedinacna vremena reagovanja u iznenadnim i neocekivanim uslovima, kada je verovatnoca kocenja vodeceg vozila mala, znatno veca od prosecnog vremena reagovanja (tab. 6). Na primer, svi vozaci imaju znatno vece vreme reagovanja pri kocenju na usponu, pri ukrštanju sa sporednim putem, po izlasku iz krivine i u slicnim situacijama.

\section{Uticaj realnog vremena reagovanja sistema na bezbednost saobracaja}

Vreme reagovanja utice na bezbednost saobracaja kao vremensko-prostorna i saobracajnotehnicka komponenta, preko puta reagovanja. Put reagovanja $S_{r}$ je linearna funkcija brzine i vremena reagovanja sistema $\mathrm{v}-\mathrm{v}$ (sl. 3). To znaci da se put reagovanja povecava proporcionalno povecanju vremena reagovanja, pa zakljucujemo da produžavanje vremena reagovanja skracuje put do opasne prepreke i stvara latentnu opasnost za nastajanje nezgode. Sa sl. 3 i na osnovu srednjih vrednosti vremena reagovanja (tab. 3)

Ekstremne vrednosti pojedinacnih vremena reagovanja uporednog uzorka

\begin{tabular}{|c|c|c|c|c|}
\hline $\begin{array}{c}\text { Uslovi } \\
\text { merenja }\end{array}$ & Vozač broj & $\begin{array}{c}\text { Ekstremna } \\
\text { vrednost s }\end{array}$ & Broj merenja & $\begin{array}{c}\text { Srednja } \\
\text { vrednost s }\end{array}$ \\
\hline $45 \mathrm{~km} / \mathrm{h}$ & 38 & max. $-2,787$ & 30 & 0,826 \\
\cline { 3 - 5 } & 15 & min. $-0,402$ & 33 & 0,635 \\
\hline $60 \mathrm{~km} / \mathrm{h}$ & 37 & max. $-2,964$ & 28 & 0,754 \\
\cline { 2 - 5 } $50 \mathrm{~m}$ & 3 & min. $-0,400$ & 10 & 0,550 \\
\hline $75 \mathrm{~km} / \mathrm{h}$ & 30 & max. $-2,986$ & 12 & 0,964 \\
\cline { 2 - 5 } $100 \mathrm{~m}$ & 5 & min. $-0,413$ & 12 & 0,669 \\
\hline $60 \mathrm{~km} / \mathrm{h}$ & 35 & max. $-2,946$ & 21 & 0,797 \\
\cline { 2 - 5 } $50 \mathrm{~m}-2 \mathrm{~h}$ & 24 & min. $-0,400$ & 14 & 0,484 \\
\hline $60 \mathrm{~km} / \mathrm{h}$ & 17 & max. $-2,880$ & 11 & 0,785 \\
\cline { 2 - 5 } $50 \mathrm{~m}-5 \mathrm{~h}$ & 8 & min. $-0,405$ & 16 & 0,670 \\
\hline
\end{tabular}




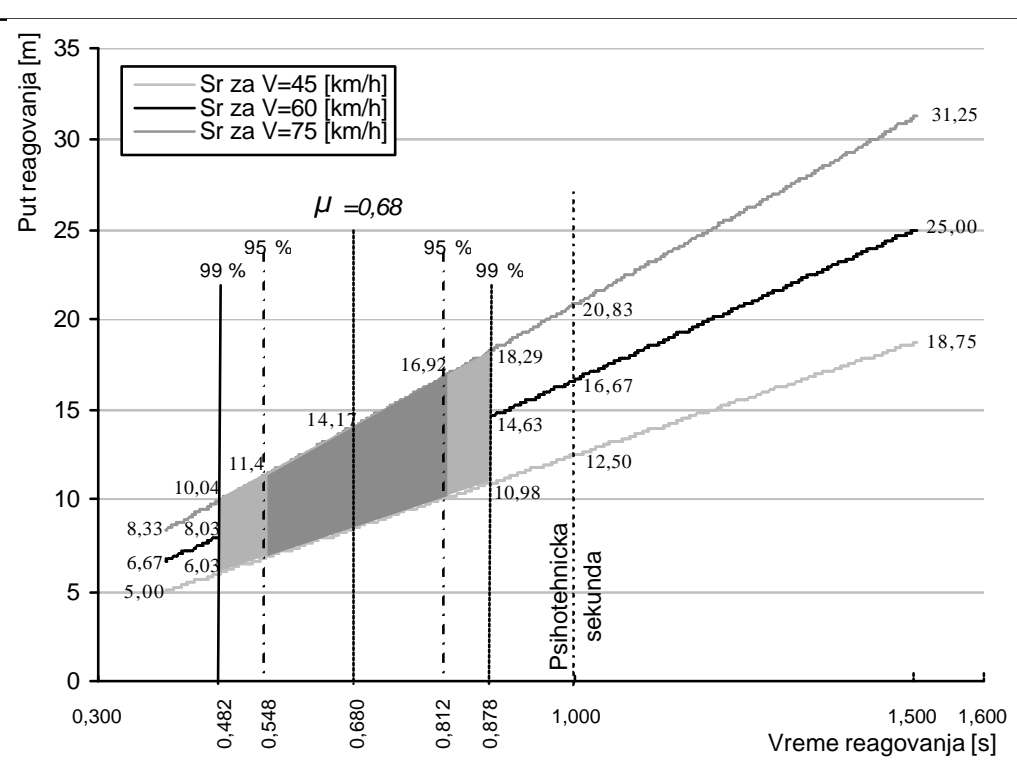

Sl. 3 - Put reagovanja u funkciji brzine i vremena reagovanja vojnika vozaca

može se zakljuciti da je vreme reagovanja vojnika vozaca znatno krace od normativnog vremena, odnosno psihotehnicke sekunde. Za analizirane brzine, na intervalu poverenja vremena reagovanja (sl. 3) put reagovanja manji je za 1,61 do $10,73 \mathrm{~m}$, u odnosu na normativni put reagovanja. Za analizirane brzine, sa grafikona (sl. 3) može se ocitati vrednost puta reagovanja, za vremena reagovanja na intervalu poverenja i uporediti sa normativnim putem reagovanja (psihotehnicka sekunda).

$\mathrm{Na}$ sl. 4. prikazan je zaustavni put, $\mathrm{S}_{\mathrm{zn}}$ za normativno i $\mathrm{S}_{\mathrm{zr}}$ za kumulativno vreme reagovanja u funkciji brzine. Za bezbednost saobracaja znacajno je da razlika ovih puteva $\mathrm{L}$, na intervalu brzine $10-100 \mathrm{~km} / \mathrm{h}$ iznosi 0,89 do $8,89 \mathrm{~m}$. U slucaju pogrešne procene vremena reagovanja ta razlika predstavlja grešku, koja se ne može apstrahovati sa stanovišta bezbednosti saobracaja. Kritickom anali-

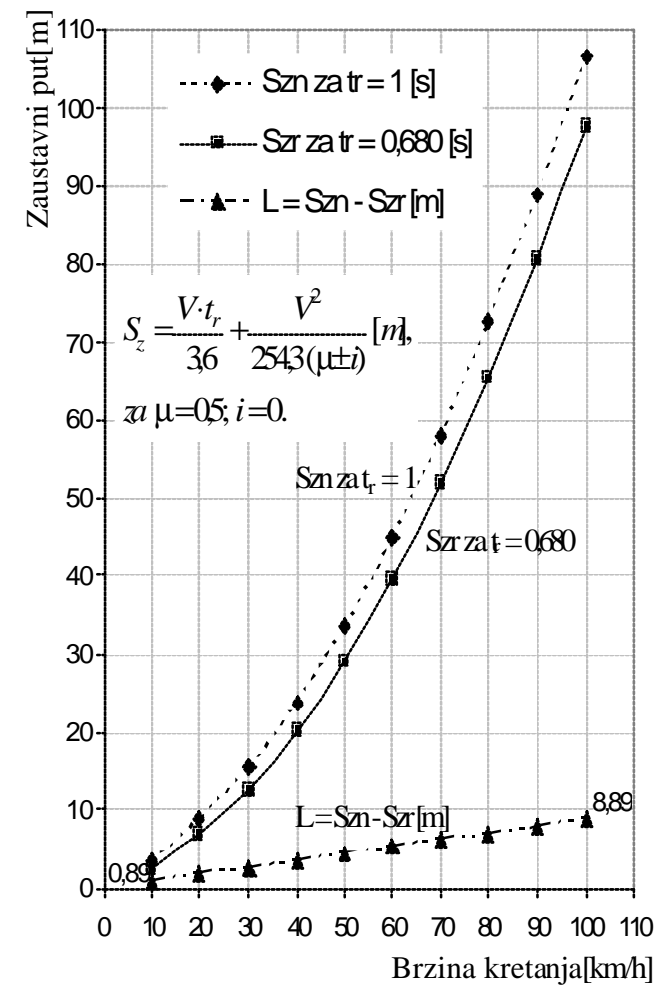

Sl.4-Zaustavni put u funkciji brzine za normativno $i$ srednje kumulativno vreme reagovanja 
zom i pravilnim izborom realnog vremena reagovanja, primereno okolnostima $u$ kojima vozac reaguje, put reagovanja može se realno odrediti, što je presudno za bezbednost saobracaja i za sve analize saobracajnog toka.

\section{Zakljucak}

Rezultati do kojih se došlo u ovom istraživanju vremena reagovanja znacajni su za prakticnu primenu i saglasni su sa rezultatima ranijih istraživanja, po svim pokazateljima. Ovo istraživanje pokazalo je da su realna vremena reagovanja vojnika vozaca znatno manja od normativnog vremena, koje se preporucuje u literaturi i od vremena reagovanja do kog se došlo u ranijim istraživanjima.

Srednje vreme reagovanja zavisi od iskustva, starosti i staža vozaca, a pojedinacno od objektivnih okolnosti u kojima vozac reaguje.

Vozaci koji brzo reaguju, u iznenadnim, nejasnim i neocekivanim situacija- ma imaju vreme reagovanja koje znatno prelazi njihovu srednju vrednost. To znaci da do punog izražaja dolazi individualnost vozaca, koja zavisi od okohnosti u kojima se reaguje, što treba imati u vidu pri svim analizama.

\section{Literatura:}

[1] Лобанов, Е. М.: Проектирование дорог и организация движения с учетом психофизиологии водителя, Транспорт, Москва, 1980.

[2] Covic, M. i saradnici: Vještacenja u cestovnom prometu, „Informator", Zagreb, 1987.

[3] Dragac, R.: Bezbednost saobracaja, II deo, Saobracajni fakultet, Beograd, 1983.

[4] Gordic, S. R.: Real no vreme reagovanja vozaca, VI simpozijum sa medunarodnim ucešcem Prevenci ja saobracajnih nezgoda na putevima 2002, bezbednost sabracaja u XXI veku, Novi Sad, oktobar 2002.

[5] Gordic, S. R. i Durutovic, S.: Merenje realnog vremena reagovanja vozaca, Tehnika, casopis Saveza inženjera i tehnicara Jugoslavije, 3/2003.

[6] Gordic, S. R.: Analiza realnog vremena reagovanja vozaca, VII simpozijum sa medunarodnim ucešcem Prevencija saobracajnih nezgoda na putevima 2004, Novi Sad, oktobar 2004.

[7] Gordic, S. R.: Analiza kretanja organizovanog kolonskog saobracaj nog toka i kri terijuma njegove efi kasnosti, magistarski rad, TVA KoV, Zagreb, 1983.

[8] Guilford J. P.: Fundamental Statistics in Psychology and Education, Me Graw-Hill, New York, 1956.

[9] Gordic, S. R.: Efi kasnost organizovanog vojnog kolonskog saobracaj nog toka, doktorska di sertacija, Vojna akademija - Odsek logistike, Beograd, 2005. 